\title{
Oceanic and local environmental conditions as forcing mechanisms of the glass eel recruitment to the southernmost European estuary
}

\author{
Carmen Arribas $^{\mathrm{a} *}$, Carlos Fernandez-Delgado ${ }^{\mathrm{a}}$, Francisco J. Oliva-Paterna ${ }^{\mathrm{b}}$, Pilar \\ Drake $^{\mathrm{c}}$
}

${ }^{a}$ Departamento de Zoología, Edificio Charles Darwin, $3^{a}$ planta, Campus Universitario de Rabanales, Universidad de Córdoba, 14071 Córdoba, Spain.

${ }^{b}$ Departamento de Zoología y Antropología Física, Facultad de Biología, Universidad de Murcia, 30100 Murcia, Spain.

${ }^{c}$ Instituto de Ciencias Marinas de Andalucía (CSIC), Polígono Río San Pedro s/n, Apartado Oficial, 11510 - Puerto Real, Cádiz, Spain.

*Corresponding author:

Email address: ba2arloc@uco.es ;Tel./fax: +34 957218605.

Present address: Departamento de Zoología, Edificio Charles Darwin, $3^{\text {a }}$ planta,

Campus Universitario de Rabanales, Universidad de Córdoba, 14071 Córdoba, Spain.

\section{Abstract}

In order to asses the main oceanic and local environmental traits forcing the glass eel Anguilla anguilla (L., 1758) recruitment to the southernmost European estuary, glass eels recruitment pattern to the Guadalquivir River estuary was studied during nine successive migration seasons (June 1997-December 2006) using a fishery-independent experimental survey at three sampling sites in the estuary. A clear seasonal pattern was observed: density was highest between late autumn and spring with two migration peaks, and lowest during summer. Short-term (inter-month) changes in glass eel density were partially driven by local environmental variables, such as estuarine turbidity, local rainfall and water temperature. Long-term (inter-year) changes were positively correlated with oceanic factors related to recruitment success (NAO index and primary production at the spawning area) as well as local environmental factors (westerly and southerly wind mixing indices and rainfall). Spatial changes in glass eel density within the estuary depended on tidal and light situations; however, maximum densities were mainly observed at diurnal and/or nocturnal flood tides. Although it has been widely known since the 1980s that the abundance of European glass eels is decreasing, during 
this study there was no evidence of a declining trend, probably because the time series was not long enough.

Keywords: glass eels, Anguilla anguilla, recruitment, environmental factors, Guadalquivir Estuary.

\section{Introduction}

The European eel, Anguilla anguilla (L., 1758), has a long and complex life cycle that is still not known in its entirety. Eels spawn somewhere in the Sargasso Sea, between 22$30^{\circ} \mathrm{N}$ and $48-65^{\circ} \mathrm{W}$ (Tesch, 2003). From there, eel larvae are passively and/or actively transported by marine currents towards the continental shelf of the Atlantic coast of Europe and North Africa (van Ginneken and Maes, 2005). The duration of this transatlantic migration remains highly controversial, with estimates oscillating from 6 months to more than 2 years (Kettle and Haines 2006; Bonhommeau et al., 2008a,b, 2009). At the end of their transoceanic migration, the willow leaf-shaped, translucent, leptocephalus larvae metamorphoses into glass eels and colonize coastal, estuarine and river habitats (Daverat et al., 2006) using selective tidal stream transport (McCleave and Wippelhauser, 1987). Food availability in the spawning area and during their long and complex oceanic migration from the Sargasso Sea to European coasts may affect the survival of leptocephalus larvae (Bonhommeau et al., 2008a,b). At the same time, large scale oceanic features, estimated with the winter NAO (North Atlantic Oscillation), GSI (Gulf Stream Index) and PEA (Potential Energy Anomalies) indices, may also affect the journey of leptocehalus to the continental shelf (Bonhommeau et al., 2009).

After metamorphosis of leptocehalus, local hydrological and/or climatic factors play a preponderant role in determining the migration of glass eels towards estuarine habitats, as well as their spatiotemporal abundance patterns within them (Gascuel et al., 1995). It has been widely reported that environmental factors, such as moonlight, river flow, tidal cycle, conductivity, salinity and water temperature, affect the freshwater migration of glass eels and elvers on northern European coasts (Gascuel 1986; Elie and Rochard, 1994; Ciccotti et al., 1995; White and Knights, 1997; Jellyman and Lambert, 2003; Edeline et al., 2005). However, there is very little information on the glass eel in the southernmost estuaries of its European distribution area (Arias and Drake, 1990; Drake 
and Arias 1991; Zompola et al., 2008). Nevertheless, the importance of the environmental factors affecting glass eel migration differs according to the location, estuary characteristics and physiological status of the eels (Elie and Rochard, 1994; Zompola et al., 2008). For example, although most authors have found that there is an eel recruitment period from winter to spring along the European Atlantic (Elie and Rochard, 1994; Gascuel et al., 1995; Dasaunay and Guerault, 1997) and Mediterranean coasts (Gandolfi et al., 1984; Cicotti et al., 1995; Zompola et al., 2008), Zompola et al. (2008) suggests that there is a time delay between northern and southern regions. This geographical shift may be explained by the latitudinal cline found in the timing of glass eel arrival to the different zone of the continental shelf (Tesch, 2003). Furthermore, since low water temperatures reduce the locomotive activity of glass eels (Elie and Rochard, 1994; Edeline et al., 2006), the latitudinal differences in their recruitment period to estuaries could be also related to differences in seasonal temperature patterns along the European coast. Therefore, additional knowledge on the behaviour of this species in its southernmost distribution areas could contribute to a better understanding of latitudinal variations in the continental recruitment of the European glass eel.

During their upstream migration from the sea into rivers, glass eels are harvested commercially in several European and North African countries (Gascuel et al., 1995). Therefore, most available multiyear temporal series on glass eel recruitment to European estuaries are based on fishery statistics and/or on scientific surveys conducted with commercial catches. However, fishery-independent surveys lasting more than two years are very scarce. Data based on glass eel fisheries generally suffer from heterogeneity (sampling methods and protocols) and temporal bias (fishing season). Furthermore, although commercial catches may provide relatively reliable information after standardization (CPUE, Catch Per Unit Effort), the results may still sometimes be biased; therefore, using average CPUE as a glass eel abundance index can be unreliable (Gascuel et al., 1995). In the Guadalquivir Estuary, not regulated glass eel fishery has traditionally occurred until November of 2010, but there are no official statistics on commercial catches (Sobrino et al., 2005).

In this context, the analysis of a ten-year data set (nine complete glass eel recruitment periods) obtained by monthly fishery-independent experimental surveys in the Guadalquivir River, the southernmost estuary of all large European rivers, may 
significantly contribute to gaining further insights into the temporal recruitment of European glass eels to estuaries in relation to environmental conditions. Currently, the timing and volumes of freshwater inflow to the Guadalquivir estuary are managed for irrigation purposes of cultivated land situated along the river course. However, the possible effects of this water management strategy on the function of the estuary as a transitory habitat for glass eels and elvers are not taken into account. This control of the river discharges generally means a reduction in the river inflow to the estuary and alters the natural pattern of estuarine environmental gradients (Baldó et al., 2005).

Furthermore, as freshwater plume may represent a significant cue to fish that an estuary is nearby (Kingsford and Suthers, 1994), and thus a low river inflow could hamper the glass eels' ability to orientate towards estuarine areas by following physicochemical gradients (Edeline et al., 2005).

Under the assumption that glass eel recruitment to the studied estuary is mainly limited by the amount of glass eels successfully arriving to the adjacent continental shelf, the estuarine glass eel density should show temporal (inter-month and inter-year) changes that cannot be explained by changes in the estuarine environmental conditions but rather by changes in the oceanic conditions at the spawning area and/or along the entire larval transatlantic journey. Alternatively, if environmental conditions in the estuary are relevant in determining glass eel density patterns within the estuary, then a significant proportion of the observed temporal variation in glass eel density should be explained by changes in estuarine environmental conditions. The aim of this study was to assess which environmental variables are currently governing the spatiotemporal distribution of European glass eels within the Guadalquivir estuary and to what extent, so we analyzed monthly estuarine densities between June 1997 and December 2006 in relation to environmental conditions.

\section{Material and methods}

\subsection{Study Area}

The Guadalquivir River estuary (southwest Spain: $36^{\circ} 47^{\prime}-37^{\circ} 25^{\prime} \mathrm{N}, 4^{\circ} 58^{\prime}-7^{\circ} 00^{\prime} \mathrm{W}$ ) is a well-mixed system with a longitudinal salinity gradient (Vanney, 1970). The freshwater input to the estuary is regulated from the Alcalá del Río dam located at $110 \mathrm{~km}$ from the 
river mouth (Fig. 1). The tidal influence reaches until the dam and the mean tidal range is $3.5 \mathrm{~m}$ in the outer area. For most of the study period, the estuarine hydrodynamic was under low riverflow discharge conditions $\left(<40 \mathrm{~m}^{3} \mathrm{~s}^{-1}\right)$ and the estuary was tidallydominated (Díez-Minguito et al., 2012). Thus, the location of the estuarine mixing zone changes from high tide to low tide as well as seasonally. The salinity gradient shows both long-term (seasonal) and short-term (tidal and dam management-related) displacement along the river course (Drake et al., 2002). On average, the isohaline $5 \%$ boundary (between the oligohaline and mesohaline zones) is situated $25 \mathrm{Km}$ upstream from the river mouth at low tide ( $35 \mathrm{Km}$ at high tide), while the isohaline $18 \%$ boundary (between the mesohaline and polyhaline zones) is situated $5 \mathrm{Km}$ upstream at low tide (15 Km at high tide).

Three sampling sites were selected at $8 \mathrm{Km}$ (Bonanza, Bo), $20 \mathrm{Km}$ (La Esparraguera, Es) and $32 \mathrm{Km}$ (Tarfía, Ta) upstream from the estuary mouth respectively. The main width of this stretch at high tide ranges between $400 \mathrm{~m}$ at the innermost sampling station (Ta) and $728 \mathrm{~m}$ at the outermost station (Bo) (Fig. 1).

\subsection{Sampling protocols}

The abundance of glass eels was estimated with the local fishery gear that has been traditionally used for the commercial caught of glass eels in the Guadalquivir estuary (for more details see Fig 2 in Sobrino et al., 2005). Samples were taken monthly from June 1997 to December 2006 (nine complete glass eel recruitment periods) at each new moon, from a boat anchored where the water column depth was approximately $3 \mathrm{~m}$ at low tide. Four passive hauls were carried out at each sampling station with three $10 \mathrm{~m}$ long nets ( $1 \mathrm{~mm}$ mesh; net opening $2.5 \mathrm{~m}$ wide and $3 \mathrm{~m}$ long) working in parallel during the first $2 \mathrm{~h}$ of the diurnal and nocturnal flood and ebb tides. As a major fish activity was expected after each inversion of the tidal current and fish tend to migrate in group, the timing and duration of hauls were chosen in order to get representative samples. The total catch was emptied into a calibrated container and its volume was estimated.

Thirteen litres of the collected material, or the total volume when the catch was smaller, were randomly sampled using a calibrated beaker. Glass eels were counted and weighed (wet mass; g) in the laboratory. 
Water temperature, salinity and turbidity were measured at the start of each haul. The current speed during sampling was estimated with a digital flowmeter (HYDRO-BIOS ${ }^{\circledR}$, $438110)$ placed near the nets: mean currents speed were $0.53,0.52$ and $0.58\left(\mathrm{~m} \mathrm{~s}^{-1}\right)$ at Bo, Es and Ta, respectively. The daily flow $\left(\mathrm{m}^{3} \mathrm{~s}^{-1}\right)$ of freshwater discharges from the Alcalá del Río dam was provided by the Regional River Authority (Confederación Hidrográfica del Guadalquivir). Rainfall in the area during the study period was obtained from the meteorological station of El Palacio situated in the National Park of Doñana close to the studied estuarine zone, and the local wind speed and direction were obtained from the Naval Base of Rota (Cadiz) (Fig. 1). Finally, NAO index values (defined as the difference in pressure between Lisbon and Reykjavik) were taken from the National Center for Atmospheric Research (NCAR, USA) database (http://www.cgd.ucar.edu/cas/jhurrell/indices.html). Primary production (PP) data from the Bermuda Atlantic Time-series Study (BATS) station were used to determine the food availability for larvae in the European eel spawning area (http://bats.bios.edu/bats_form_prod.html).

\subsection{Data analysis}

Abundances of glass eels are given as the number of individuals per volume of filtered water. There were high temporal (inter-monthly + interannual) variations in the glass eel recruitment to the estuary. Therefore, the abundance data were transformed prior to the analyses as follows: in order to analyse the seasonal component, the interannual variation was omitted by expressing the average density at each monthly sampling as a percentage of the sum of the twelve monthly densities of the corresponding year; and for the spatial distribution analysis, the inter-monthly variations were omitted by expressing densities at each diel-tidal and site situation as a percentage of the sum of the twelve densities of the corresponding monthly sampling. To avoid aberrant percentages due to low densities, the spatial distribution was only tested during the high recruitment period (October to May). The resulting relative glass eel densities (\%) were $\arcsin \sqrt{x}_{\mathrm{X}}$ transformed prior to statistical analyses in order to normalize data and reduce the heterogeneity of variances. The statistical significance of seasonal changes in density were ascertained using one-way ANOVA (factor: month), whereas diel-tidal and spatial differences were tested by using two-way ANOVA (factors: diel-tidal situation and site). For each date and site, four different diel-tidal situations were considered: diurnal 
flood (DF), nocturnal flood (NF), diurnal ebb (DE) and nocturnal ebb (NE). Factors detected to be significant by ANOVA were analyzed further using the Tukey unequal $\mathrm{N}$ HSD test. A 5\% significance level was considered for all statistical tests used. When significant interactions were found, the comparisons of means for the main effects of these factors were considered secondary.

To ascertain interannual changes in A. anguilla glass eel densities, monthly fluctuations within each year were overcome by resampling (drawing repeated samples from the original data set). That is, for each year, several annual mean density estimates were calculated during the maximum recruitment period by including four monthly estimates each time. The annual mean estimates obtained were then used to build a triangular matrix containing differences among any pair of annual means, both within and between years. Finally, to determine statistically significant interannual differences, a permutation test was implemented using the ANOSIM programme of the computer software package PRIMER (Plymouth routines in multivariate ecological research) (Clarke and Green, 1988).

As a measure of the freshwater inflow, the freshwater volumes discharged from the dam to the estuary during the week $\left(\mathrm{V}_{7}\right)$, fortnight $\left(\mathrm{V}_{15}\right)$ and month $\left(\mathrm{V}_{30}\right)$ before each sampling date were estimated from daily freshwater flow $\left(\mathrm{Hm}^{3} \mathrm{~s}^{-1}\right)$. Rainfall was estimated as the average rainfall recorded during the week $\left(\mathrm{R}_{7}\right)$, fortnight $\left(\mathrm{R}_{15}\right)$ and month $\left(\mathrm{R}_{30}\right)$ before each sampling date $\left(\mathrm{m}^{-2}\right)$. Similarly, the wind speed and direction were obtained during the week, fortnight and month before each sampling date. NAO winter (December to March) index values were used as an indicator of the climatic conditions. PP data from BATS were used as an indicator of food availability for eel larvae in the spawning area (Bonhommeau et al., 2008a, b). Assuming that the European eel spawns mainly from March to June (van Ginneken and Maes, 2005), PP was integrated from March to July to estimate the annual productivity in the Sargasso Sea in the period of maximum leptocephalus density.

A stepwise least-squares multiple regression was used to explore the relationship between the environmental variables and monthly changes in glass eel density (individuals $10^{5} \mathrm{~m}^{3}$ ) throughout the studied period, as well as during the high recruitment period. The environmental variables included in the regression analysis 
were: monthly mean water temperature $\left(\mathrm{T},{ }^{\circ} \mathrm{C}\right)$, salinity $(\mathrm{S})$ and turbidity $\left(\mathrm{T}_{\mathrm{u}}, \mathrm{NTU}\right)$ on each sampling date; freshwater volumes $\left(\mathrm{hm}^{3}\right)$ discharged from the dam to the estuary during the week $\left(\mathrm{V}_{7}\right)$, fortnight $\left(\mathrm{V}_{15}\right)$ and month $\left(\mathrm{V}_{30}\right)$ before each sampling date; the average rainfall $\left(\mathrm{m} \mathrm{m}^{-2}\right)$ recorded during the week $\left(\mathrm{R}_{7}\right)$ fortnight $\left(\mathrm{R}_{15}\right)$ and month $\left(\mathrm{R}_{30}\right)$ before each sampling date; the wind mixing index (wind speed ${ }^{3}$ ) and wind direction obtained during the week, fortnight and month before each sampling date; and monthly PP in the Sargasso Sea. Before they were included in the regression analyses, the turbidity, freshwater volume, rainfall, wind mixing index, PP and density data were ln $(\mathrm{X}+1)$ transformed to normalize the data and reduce the heterogeneity of variance. Since there may be a delay between the environmental cues and the response of the glass eels, time-lagged (to a 3 month lag and 36 month lag for local variables and PP at the spawning area respectively) cross-correlations were performed between glass eel density and environmental variables. The lags that showed the highest significant correlations were chosen to be tested with the model. To reduce the type I error (autoregression in glass eel density and some environmental variables), only variables with $\mathrm{P}$ $<0.005$ were included in the final model. Moreover, we assessed the relationship between the mean annual estuarine density estimates and the environmental variables by determining the corresponding Pearson correlation coefficients. For the NAO winter index and PP in the Sargasso Sea, the coefficient correlation with glass eel density was estimated until we reached a 3 year lag and the highest significant correlation was obtained in the results.

\section{Results}

\subsection{Temporal patterns}

From June 1997 to December 2006 there were considerable temporal changes in the environmental conditions of the Guadalquivir River estuary (Fig. 2). Water temperature showed a strong, regular seasonal trend (from $17.7 \pm 0.94^{\circ} \mathrm{C}$ in January to $25.9 \pm$ $0.90^{\circ} \mathrm{C}$ in July on average) and the mean annual water temperature was $19.2 \pm 0.28^{\circ} \mathrm{C}$. Salinity only showed a seasonal trend in rainy years (1997-98 and 2000-2003), with minimum values in winter and/or spring and maximum values in summer (Fig. 3). On average, the minimum salinity was recorded in January $(8.5 \pm 2.82)$ and maximum salinity in July $(16.4 \pm 2.68)$. Mean annual water turbidity was $103.3 \pm 6.72 \mathrm{NTU}$, and 
oscillated between $30.9 \pm 56.19$ NTU in July and 198.4 \pm 58.93 NTU in December (Figs. 2 and 3).

The environmental conditions were most stable, with only small changes between months, in the period when temperatures were highest, whereas low stability was observed from late autumn to early spring. Hence, the warm period was characterized by relatively low turbidity, high salinity (low rainfall and low freshwater input from the dam) and moderate inter-year variation in environmental conditions; however, from late autumn to early spring these variables showed larger inter-month (short-term) and interyear (long-term) variation (Figs 2 and 3).

Although glass eel recruitment to the Guadalquivir estuary occurred throughout the year, a clear seasonal pattern was observed (Fig. 3 (f)): on average, low glass eel densities occurred from June to September (mean density 0.09 individuals $\mathrm{m}^{-3}$ in August), whereas higher recruitment was observed from October to May (mean density 1.91 individuals $\mathrm{m}^{-3}$ in December). Estuarine glass eel density tended to peak twice a year (Fig. 3(f)): in autumn/winter and spring respectively. The ANOVA results indicate significant seasonal differences between summer densities and those from late autumn to early spring (Table 1). Similarly, the ANOSIM results showed that inter-year differences in glass eel density were also significant $(p<0.05$; Table 2$)$, with maximum and minimum annual means in $2001(202.1 \pm 133.44)$ and $2005(86.9 \pm 49.71)$ respectively.

The significant variables $(p<0.005)$ identified with the stepwise least-squares multiple regression analysis of glass eel density (D) in relation to environmental variables were water turbidity $\left(\mathrm{T}_{\mathrm{u}}\right)$, rainfall recorded during the fortnight $\left(\mathrm{R}_{15}\right)$ before each sampling date and water temperature $(\mathrm{T})$. These variables explained $62.2 \%$ of the total variance of the dependent variable: $\operatorname{Ln} \mathrm{D}=2.36+0.07 \mathrm{Ln} \mathrm{T}_{\mathrm{u}}-0.08 \mathrm{~T}+0.10 \mathrm{Ln} \mathrm{R}_{30}$

The stepwise least-squares multiple regression analysis of the effects of environmental variables on monthly glass eel density during the period of maximum estuarine recruitment showed that $35.4 \%$ of the total observed variance in the dependent variable was explained by water turbidity $\left(\mathrm{T}_{\mathrm{u}}\right)$ and southwesterly winds $(\mathrm{Sw})$ according to the following model: $\mathrm{Ln} \mathrm{D}=1.49+0.63 \mathrm{Ln} \mathrm{T}_{\mathrm{u}}+0.09 \mathrm{Sw}$. A statistically significant 
positive correlation was observed between mean annual glass eel densities during the high recruitment period, primary production at the spawning area and the NAO index during the previous reproductive period (Fig. 4 (a)). There were also positive correlations between eel densities and westerly and southerly wind mixing indices during the high glass eel recruitment period (Fig. 4 (b)). However, correlations between annual glass eel recruitment and northerly and northeasterly wind mixing indices were negative (Fig. 4 (c)). For the more local estuarine environmental variables, only a significant positive correlation was observed between the mean annual glass eel density and rainfall during the high recruitment period $(\mathrm{r}=0.67 ; p<0.05)$.

\subsection{Spatial patterns}

On each sampling date the water temperature was almost homogeneous (ANOVA, $p<$ 0.05) along the entire studied stretch irrespective of the tidal situation (flood v. ebb), although there was a slow decrease from midday to dawn (Fig.5 (a)).

Conversely, salinity decreased gradually and significantly upstream (ANOVA, $p>$ 0.05 ), with mean values of $19.2 \pm 1.29$ and $4.4 \pm 0.39$ at 8 and $32 \mathrm{~km}$ from the river mouth respectively. Furthermore, water masses with specific salinities showed clear longitudinal seaward displacement between each high and low tide, and the tidal displacement was approximately equal to the inter-site distance (Fig. 5(b)).

Turbidity also showed spatial and tidal changes (ANOVA, $p<0.05$ ), and the highest values were found at the inner sampling sites $(32 \mathrm{Km}$, Tarfía, and $20 \mathrm{~km}$, La Esparragera, from the river mouth) during floods (191.7 NTU, on average), while the lowest values were found in the outer zone ( $8 \mathrm{~km}$ from the river mouth) during ebbs (99.9 NTU, on average) (Fig. 5(c)).

Although there were significant differences (ANOVA, $p<0.05$; Table 1) in the glass eel density between sample sites depending on tidal and light situations, a consistent daily tidal pattern was not observed in the studied estuarine reaches. On average glass eel densities were higher during floods than during ebbs at the three sampling sites. However, whereas the glass eel density was significantly higher during daytime flood tides than during the night at the outermost sampling site $(8 \mathrm{Km}$, Bonanza, from the 
river mouth), it was significantly higher during the nocturnal flood tide at the innermost sampling site (32 Km, Tarfía, from the river mouth). This suggests a change in the day/night migratory behaviour of glass eels along the estuarine gradient (Fig. 5 (d)).

\section{Discussion}

Although recruitment of glass eels to the Guadalquivir River estuary occurred throughout the year, there was a clear seasonal pattern. As in other European Atlantic estuarine habitats of Portugal (Domingos, 1992; Bessa and Castro, 1995), northern Spain (Gandolfi-Hornyold, 1931; Lara, 1994) and France (Désaunay et al., 1996), in the studied estuary glass eel density was highest between late autumn and spring and lowest during summer. When data from the entire year were analyzed, turbidity was the most important variable in determining the number of glass eels entering the Guadalquivir estuary, followed by local rainfall and temperature. Turbidity also best explained the changes in the estuarine glass eel density in the high recruitment period. That is, the highest glass eel densities were observed when the river was in a rainfall-dependent hydrological regime, with increased water turbidity, coinciding with periods of low to moderate water temperatures. Among the numerous environmental factors that might influence the estuarine catches of glass eels, water turbidity has been previously reported to be significant in the Gironde estuary $\left(45^{\circ} 5^{\prime} \mathrm{N}, 1^{\circ} \mathrm{W}\right)$ and Arno River $\left(43^{\circ}\right.$ $\left.\mathrm{N}, 10^{\circ} 2^{\prime} \mathrm{E}\right)$. Furthermore, Jellyman and Ryan (1983) found a very strong positive relationship between water flows and elver migration due to rainfall increasing freshwater outflow and turbidity in estuaries. Gandolfi et al. (1984) hypothesized that increasing flows may have a positive influence on upstream migration. In Mondego estuary $\left(40^{\circ} 8^{\prime} \mathrm{N}, 8^{\circ} 50^{\prime} \mathrm{W}\right)$ glass eel abundance was favoured by high river flows (Domingos et al., 1992). Intense rainfall reduces the salinity values, and glass eels swim driven by positive rheotaxis towards water with low salinity levels (Tosi et al., 1989). This behaviour can be enhanced by the existence of an odoriferous cue in freshwater (Creutzberg, 1961) caused by the presence of eels (Miles 1968,) or traces of geosmin (Tosi and Sola, 1993) in continental waters. Thus, an increase in rainfall, erosion and flow could change the composition of the dissolved or particulate components of the water and elicit the migratory response. In the studied estuary, an increase in the freshwater discharges from the dam is associated to estuarine salinity reduction (Baldó et al., 2005), and to the development of a turbidity plume that may extend over several 
hundred $\mathrm{km}^{2}$ outward the estuary mouth (Navarro et al. 2012). Therefore, freshwater discharges may be positively affecting glass eel recruitment by creating a turbid plume in the open sea, which acts as an estuarine cue for glass eels (Martin, 1995; Zompola et al., 2008). Conversely, freshwater requirements for certain human activities may reduce the size of the estuarine plume. However, the dam riverine inflow was not selected by the models as one of the variables that significantly explained the observed variation in glass eel density. This was probably due to the fact that high dam discharges always coincided with strong rainfall and the effects of both variables on glass eels recruitment may have been confounded. Indeed, changes in freshwater inputs (dam discharges and/or rainfall) caused changes in the estuarine turbidity (Figure 2), which was the first variable selected by multiple regression models.

Numerous studies have also found that migration and river recruitment of glass eels are negatively correlated with temperatures (Gascuel, 1986; Elie and Rochard, 1994; Martin, 1995), which suggests that temperature has a relevant effect on the glass eel's migratory behaviour. In northerly locations eels may enter less inland than in southern locations, where water temperatures are warmer. Furthermore, if there is seasonal variation in migratory cues that induces elvers to commence their migration, it would also be reasonable to assume that there could be some latitudinal cline to the cues as well (Martin 1995). That is, the timing of the movement into freshwater may be inversely related to latitude as a result of the lower temperatures of more northerly rivers (Linton et al., 2007). Indeed, in the northern part of the European Atlantic coast, glass eel recruitment takes place later (spring-summer) than in southern regions (autumn-winter) (see Table 3). This time delay could be explained by the difference in the seasonal dynamics of water temperature (Tesch, 2003). Similarly, on the Mediterranean coast, the glass eel inshore migration showed a lag between western (autumn) and eastern regions (winter). This time delay in the arrival of glass eels could be explained by the time the larvae need to drift from Gibraltar to the most eastern regions (2000 Km to Egypt).

Several migration peaks are common in many estuaries and depend on two main factors: the reproductive period and the water temperature (Lafaille et al. 2007). Two migration peaks were generally observed in Guadalquivir River, which has also been found on the Gulf of Cadiz (Arias and Drake, 1990) and Mediterranean coasts (Gandolfi 
et al., 1984; Lefebvre et al., 2003). Although reproduction occurs in the Sargasso Sea during the entire year, the main reproductive peak is in spring (McCleave, 1993). The Lagragian model by Kettle and Haines (2006) suggests that the western part of the Sargasso Sea favours successful transatlantic migration to all latitudes of the adult range in Europe and North Africa, which could explain the winter peaks observed along European coasts. However, as McCleave (1993) hypothesized, this model also proposes an additional transatlantic migration route from the northeast corner of the spawning region toward southern Europe and North Africa, which could explained the second migration peak in the Guadalquivir River. That is, although only one cohort recruits each year (Desaunay et al., 1996; Desaunay and Guerault, 1997), glass eels arrive in successive waves to European coasts from different routes (Boetius and Harding, 1985). Furthermore, the preference of glass eels for either freshwater or saltwater depends on body condition and the timing of arrival to the continental shelf (Edeline et al., 2005), which may also lead to density peaks in estuarine recruitment.

During the long oceanic larval migration, changes in prevailing current patterns could modify the magnitude of glass eel recruitment to fresh water habitats (Kleckner and McCleave 1985). Indeed, oceanographic changes have been suggested to be one of the causes of the substantial annual fluctuations in recruitment in European and American eels (Moriarty and Dekker 1997). Similarly, yearly variations in European eel recruitment have been related to primary production (PP) in the spawning area (Bonhommeau et al., 2008a) and to the North Atlantic Oscillation (NAO) winter index, which may force changes in fronts and currents that affect spawning and larval survival (Friedland et al. 2007). In the Guadalquivir estuary, the mean annual recruitment varied significantly during this ten year study (1997-2006), and a significant positive correlation was found between glass eel catches in the Guadalquivir River and the 9month lagged time-series of the PP and NAO indices. Food availability in the Sargasso Sea is critical for early life stages as it determines whether larvae can rapidly reach the size that will allow them to drift into the North Atlantic current. Moreover, oceanic features may affect the long leptocephalus migration towards the estuary (Knights, 2003). Therefore, the results of this study suggest a link between annual estuarine recruitment and eel leptocephalus successfully reaching the coast. 
Although correlations between glass eel recruitment and indicators of climatic conditions (PP and NAO, among others) have been observed in other estuaries (Curry and McCartney, 2001; Knights, 2003; Bonhommeau et al., 2008a), the results are not consistent with the duration of the oceanic larval migration. There are currently two theories about the mechanisms of larval transport from the spawning area to the coastal habitats of different continents. One theory suggests that there is passive, variable, multi-year ( 2 to 3 years between hatching and glass eel recruitment) oceanic transport (McCleave; 1993; Tesch; 2003; Kettel and Haines, 2006; Bonhommeau et al., 2008a), while the other theory is that larval transport of European eels is a short active process of only 7 to 9 months, including the time of metamorphosis (Arai et al., 2000). In this study, the 9 month lag observed between the annual mean glass eel recruitment and annual mean PP and NAO indices is in better agreement with the duration of the active larval transport proposed by some authors (Arai et al., 2000).

After eel larvae have arrived successfully to the coast, local epiphenomena, which can even mask the oceanic dynamics (Elie and Rochard, 1994), may also contribute to the year to year variation in glass eel recruitment to estuaries. That is, the variability in the annual recruitment depends on the quantity and physiological state of glass eels that arrive to the coast as well as the local conditions (Jellyman and Lambert, 2003). In the Guadalquivir River, recruitment was higher in years with higher rainfall and westerly and southerly wind mixing indices, whereas a negative correlation was observed between northerlies and the annual estuarine glass eel recruitment. The wind pattern is especially relevant as a factor that modulates biological processes in the Gulf of Cadiz: the predominance of westerlies and precipitations is linked to increases in PP due to the generation of upwelling events (Huertas et al., 2006; Navarro and Ruiz, 2006). Westerly winds advect the surface seawater towards the area of the inner shelf that is influenced by the Guadalquivir River (García Lafuente and Ruiz, 2007); whereas, southerlies and northerlies may force surface seawater towards the coast or to the open sea respectively (I. Leinz, personal communication). Therefore, rainfall and westerly winds may generate more productive environmental conditions in local shelf waters, which favour growth, survival and retention of leptocephali during the final step of their oceanic migration. However, southerlies may facilitate and northerlies hinder the later transport of metamorphosed glass eels towards freshwater habitats of the Gulf of Cadiz. 
Within estuaries, glass eels use tidal movements as a migration vector: they stay buried in the bottom during the ebb tide and migrate to the water column during the flood tide (Deelder, 1952, 1960; Creutzberg, 1961; Gascuel, 1986). This behaviour of hiding in the ebb tide is only complete and systematic in freshwater (Gascuel et al., 1995), whereas in brackish areas it is partial (I. Cantrelle, umpublished works). The catches are usually two to ten times larger in flood tides than ebb tides (Creutzberg, 1961). Nevertheless, no relation has been observed between estuarine catches of glass eels and the tide stage (Deelder, 1952). It has been suggested that glass eels need to stop their inward migration as they approach freshwater to undergo physiological and behavioural changes (Deelder, 1960). Indeed, in the outermost zone of the Guadalquivir estuary (polyhaline region), densities in the flood tide were always greater than those in the ebb tide irrespective of light conditions. In contrast, decreased and increased densities in diurnal and nocturnal flood tides were observed at the innermost sampling site (oligohaline region). That is, physiological and behavioural changes in glass eels seemed to occur gradually along the salinity gradient in the brackish zone of Guadalquivir estuary. This change in glass eel migration behaviour may be due to individuals being in a different stage: when non-pigmented glass eels arrive at the estuary, they do not show lucifugous behaviour and so they are also caught during the day (Gandolfi et al., 1984); however, as older pigmented glass eels migrate upstream, they begin to show lucifugous behaviour and are mainly active during the night.

Not regulated glass eel fishery has traditionally occurred in the Guadalquivir estuary (Sobrino et al., 2005) until November of 2010, when it was forbidden by the Andalusian government. However, there are no official statistics on commercial catches. Furthermore, fishermen did not permit a scientific estimation of their catches, which would have allowed us evaluating the fishery effects on the glass eel density estimated in this study. Fishing boats generally catch glass eels from mid October to March, but the fishing season may last up to May, depending on the estuarine glass eel abundance and meteorological conditions (Sobrino et al., 2005). That is, since the glass eel fishery was a secondary activity for local fishermen, whenever meteorological conditions were not too adverse, the fishing effort increased when the estuarine recruitment of glass eels was stronger. Therefore, it seems reasonable to hypothesize that, without an estuarine fishery activity, the glass eel density should have displayed a more marked seasonal pattern with stronger peaks of recruitment. 
Since the 1970s, the decline in abundance of A. anguilla in European estuaries has been so dramatic that the current fishery is considered unsustainable and the stock outside safe biological limits (Dekker 2001). Possible reasons for these declines include habitat degradation and loss, the effects of chronic pollution, parasitism, and overfishing of all freshwater life stages (Moriarty and Dekker 1997). In the Guadalquivir River estuary, considerable interannual fluctuations in the densities of glass eels were observed during this ten year study, but there was no evidence of a similar trend to those found in other European estuaries, this is probably due to the fact that the time series analyzed is too short to detect the decrease. This decrease in the recruitment of the European eel and its poor conservation status (critically endangered) mean that it is critically important to gain a better knowledge of the estuarine upstream migration dynamic and the factors controlling it. Studies like this one help to increase this knowledge, which is necessary for improving conservation management policies for the recovery of this species.

\section{Conclusions:}

The results of this study suggest that the temporal variation observed in the glass eel density within the Guadalquivir estuary seems to respond to a combination of several oceanic and local environmental conditions which may be acting as forcing mechanisms of the oceanic survival and transport of eel larvae, as well as on the ulterior glass eel migration to the estuary. On the open sea, climatic and productive conditions in the spawning area during the previous spring-early summer and the average wind mixing indices during the high recruitment period (October-May) could affect mediumterm (year to year) changes in glass eel recruitment to the estuary. Close to the estuary mouth, estuarine turbidity and southwesterly wind may have contributed to short-term (month to month) changes in the estuarine glass eel recruitment. Nevertheless, due to the shortness of the timer-series analysed (nine successive years), the interpretation of results concerning year to year variation should be considered with caution. 


\section{Acknowledgments}

We are grateful to Mr. Manuel Ruiz for his field assistance. We also wish to thank Dra. Lucía Gálvez Bravo, Dr. Enrique González Ortegón for their helpful comments on the manuscript, as well as to the anonymous reviewers who provide us useful suggestions for the elaboration of this final version. This study was financially supported by FEADER (European funds agriculture of regional development) through project $\mathrm{n}^{\circ}$ 2006000605.

\section{References}

Arai, T., Otake, T., Tsukamoto, K., 2000. Timing of metamorphosis and larval segregation of the Atlantic eels Anguilla rostrata and Anguilla anguilla, as revealed by otolith microstructure and microchemistry. Marine Biology 137, $39-45$.

Arias, A.M., Drake, P., 1990. Estados juveniles de la ictiofauna en los caños de las salinas de la bahía de Cádiz. Instituto de Ciencias Marinas de Andalucía (CSIC) y Junta de Andalucía, Cádiz, 168 pp.

Baldó, F., Cuesta, J. A., Fernández-Delgado, C., Drake, P., 2005. Efecto de la regulación del caudal del Río Guadalquivir sobre las características físicoquímicas del agua y la macrofauna acuática de su estuario. Ciencias Marinas 31, 467-476.

Bardonnet, A., Bolliet, V., Belon, V., 2005. Recruitment abundance estimation: role of glass eel (Anguilla anguilla L.) response to light. Journal of Experimental. Marine Biology and Ecology 321, 181-190.

Bessa, R., Castro, M., 1995. Variaçao sazonal dos parâmetros biometricos de meixao capturado no rio Liz. Relatórios Cientificos e Técnicos. Instituto Português de Investigaçao Maritima 4, 1-10.

Boëtius, J., Harding, E. F., 1985. A re-examination of Johannes Schmidt's Atlantic eel investigations. Dana 4, 129-162.

Bonhommeau, S., Chassot, E., Rivot, E., 2008a. Fluctuations in European eel (Anguilla anguilla) recruitment resulting from environmental changes in the Sargasso Sea. Fisheries Oceanography 17, 32-44.

Bonhommeau, S., Chassot, E., Planque, B., Rivot, E., Knap, A. H., Le Pape, O., 2008b. Impact of climate on eel populations of the Northern Hemisphere. Marine Ecology Progress Series 373, 71-80. 
Bonhommeau, S., Blanke, B., Tréguier, A., Grima, N., Rivot, E., Vermard, Y., Greiner, E., Le Pape, O., 2009. How fast can the European eel (Anguilla anguilla) larvae cross the Atlantic Ocean? Fisheries Oceanography 18 (6): 371 - 385.

Ciccotti, E., Ricci, T., Scardi, M., Fresi, E., Cataudella, S., 1995. Intraseasonal characterization of glass eel migration in the river Tiber: space and time dynamics. Journal of Fish Biology 47, 248-255.

Clarke, K.R., Green, R.H., 1988. Statistical design and analysis for a 'biological effects' study. Marine Ecology- Progress Series 46, 213-226.

Creutzberg, F., 1961. On the orientation of migrating elvers (Anguilla vulgaris Turt) in a tidal area. Netherland Journal of Sea Research 1, 257-338.

Curry, R., McCartney, M., 2001. Ocean gyre circulation changes associated with the North Atlantic Oscillation. Journal of Physical Oceanography 31, 3374-3400.

Daverat, F., Limburg, K. E., Thibault, I., Shiao, J.-C., Dodson, J.J., Caron, F., Tzeng, W.-N., Lizuka, Y., Wickström, H., 2006. Phenotypic plasticity of habitat use by three temperate eel species, Anguilla anguilla, A. japonica and A. rostrata. Marine Ecology-Progress Series 308, 231-241.

Deelder, C. L., 1952. On the migration of elvers (Anguilla vulgaris Turt.) at sea. Journal du Conseil International pour 1'Exploration de la Mer 18, 187-218.

Deelder, C. L., 1960. Ergebnisse der holländischen Untersuchungen über den Glasaalzug. Archiv für Fischereiwisssenschaft 11, 1-10.

Dekker, W., 2001. Status of the European eel stock and fisheries. Proceedings of the International Symposium, Advances in Eel Biology, University of Tokyo, 2830 September 2001. pp. 50-52.

Desaunay, Y., Guérault, D., Lecomte-Finiger, R., 1996. Variation of the oceanic larval migration of Anguilla anguilla glass eels from a two years study in the Vilaine estuary (France). Archives of Polish Fisheries 4, 195-210.

Desaunay, Y., Guerault, D., 1997. Seasonal and long-term changes in biometrics of eel larvae: a possible relationship between recuitment variation and North Atlantic ecosistema productivity. Journal of Fish Biology (supplement A), 317-339.

Díez-Minguito, M., Baquerizo, A., Ortega-Sánchez, M., Navarro, G.,Losada, M.A., 2012. Tide transformation in the Guadalquivir estuary (SW Spain) and processbased zonation. Journal Geophysical Research, doi:10.1029/2011JC007344, in press.

Domingos, I. M., 1992. Fluctuation of glass eel migration in the Mondego estuary (Portugal) in 1988 and 1989. Irish Fisheries Investigation, Series A 36, 1-4.

Drake P., Arias, A.M., Baldó, F., Cuesta, J.A., Rodríguez, A., Silva-García, A., Sobrino, I., García-González, D., Fernández-Delgado, C., 2002. Spatial and temporal variation of the nekton and hyperbenthos from a temperate European estuary with a regulated freshwater inflow. Estuaries 25, 451-468.

Edeline, E., Bardonnet, A., Bolliet, V., Dufour, S., Elie, P., 2005. Endocrine control of Anguilla anguilla glass eel dispersal: Effect of thyroid hormones on locomotor activity and rheotactic behaviour. Hormones and behavior 48, 53-63. 
Edeline, E., Lambert, P., Rigaud, C., Elie, P., 2006. Effects of body condition and water temperature on Anguilla anguilla glass eel migratory behavior. Journal of Experimental Marine Biology and Ecology 331, 217-225.

Elie, P., Rochard, E., 1994. Migration des civelles d'anguilles (Anguilla anguilla L.) dans les estuaries, modalités du phénomène et caractéristiques des individus. Bulletin Français de la Pêche et de la Pisciculture 335, 81-98.

Friedland, K. D., Miller, M. J., Knights, B., 2007. Oceanic changes in the Sargasso Sea and declines in recruitment of the European eel. ICES Journal of Marine Science 64, 519-530.

Gandolfi, G., Pesaro, M., Tongiorgi, P., 1984. Environmental factors affecting the ascent of elvers, Anguilla anguilla (L.), into the Arno River. Oebalia 10, 17-35.

García Lafuente, J., Ruiz, J., 2007. The Gulf of Cádiz pelagic ecosystem: A review. Progress in Oceanography 74, 228-251.

Gascuel, D., 1986. Flow-carried and active swimming migration of the glass eel (Anguilla anguilla) in the tidal area of a small estuary on the French Atlantic coast. Helgolander Meeresuntersuchungen 40, 321-326.

Gascuel, D., Feunteun, E., Fontenelle, G., 1995. Seasonal dynamics of estuarine migration in glass eels (Anguilla anguilla). Aquatic Living Resources 8, 123133.

van Ginneken, V.J.T., Maes, G.E., 2005. The European eel (Anguilla anguilla, Linnaeus), its lifecycle, evolution and reproduction: a literature review. Rev. Fish Biol. Fisheries 15, 367-398.

Huertas, I. E., Navarro, G., Rodríguez-Gálvez, S., Lubián, L. M., 2006. Temporal patterns of carbon dioxide in relation to hydrological conditions and primary production in the northeastern shelf of the Gulf of Cadiz (SW Spain). Deep-Sea Research II 53, 1344-1362.

Jellyman, D. J., Ryan, C. M., 1983. Seasonal migration of elvers (Anguilla spp.) into lake Pounui, New Zealand, 1974-1978. New Zealand Journal of Marine and Freshwater Research 17, 1-15.

Jellyman, D. J., Lambert, P. W., 2003. Factors affecting recruitment of glass eels into the Grey River, New Zealand. Journal of Fish Biology 63, 1067-1079.

Kettle, A. J., Haines, K., 2006. How does the European eel (Anguilla anguilla) retain its population structure during its larval migration across the Northern Atlantic Ocean? Canadian Journal of Fisheries and Aquatic Sciences 63, 90-106.

Kingsford, M. J., Suthers, I. M., 1994. Dynamic estuarine plumes and fronts: importance to samall fish and plankton in coastal waters of NSW, Australia. Continental Shelf Research 14, 655-672.

Kleckner, R. C., McCleave, J. D., 1985. Spatial and temporal distribution of American eel larvae in relation to North Atlantic Ocean current systems. Dana 4, 67-92.

Knights, B., 2003. A review of the possible impacts of long-term oceanic and climate changes and fishing mortality on recruitment of anguillid eels of the Northern Hemisphere. Science of the Total Environment 310, 237-244. 
Laffaille, P., Caraguel, J.-M., Legault, A., 2007. Temporal patterns in the upstream migration of European glass eels (Anguilla anguilla) at the Couesnon estuarine dam. Estuarine Coastal and Shelf Science 73, 81-90.

Lara, M. J., 1994. Catch statistics, capture methods, size, and development stages of glass eels in Asturias (northernwestern Spain). Bulletin of the Sea Fisheries Institute 1 (131), 31-39.

Lefebvre, F., Sergent, E., Acou, A., Lecomte-Finiger, R., Crivelli, A.J., 2003. Recrutement des civelles (Anguilla anguilla) sur la côte méditerranéenne Française: analyse comparée des caractéristiques biométriques et pigmentaires des saisons 1974-75 et 2000-01. Bulletin Français de la Pêche et de la Pisciculture 368, 85-96.

Linton, D.E., Jonsson, B., Noakes, L.G.D., 2007. Effects of water temperature on the swimming and climbing behaviour of glass eels, Anguilla spp. Environmental Biology of Fishes 78, 189-192.

Martin, M. H. (1995) The effects of temperature, river flow and tidal Cycles on the onset of glass eel and elver migration into fresh water in the American eel. Journal of Fish Biology 46, 891-902.

McCleave, J. D., Wipplehauser, G. S., 1987. Behavioral aspects of selective tidal transport in juvenile American eel. In: Dadswell, M. J., Klauda, R. J., Moffitt, C. M., Saunders, R. L., Rulifson, R. A., Cooper, J. E. (Eds.), Common strategies of anadromous and catadromous fishes. American Fisheries Society, Symposium 1, Bethesda, Maryland, pp. 138-150.

McCleave, J. D., 1993. Physical and behavioral controls on the oceanic distribution and migration of leptocephali. Journal of Fish Biology, 43(Suppl. A): 243-273.

Miles, S. G., 1968. Rheotaxis of elvers of the American eel (Anguilla rostrata) in the laboratory to water from different streams in Nova Scotia. Journal of Fisheries Research Board of Canada 25, 1591-1602.

Moriarty, C., Dekker, W., 1997. Management of the European eel. Fisheries Bulletin (Dublin) 15, $125 \mathrm{pp}$.

Navarro, G., Ruiz, J., 2006. Spatial and temporal variability of phytoplankton in the Gulf of Cádiz through remote sensing images. Deep-Sea Research II 53, 1241 1260 .

Navarro, G., Huertas, I. E., Costas, E., Flecha, S., Díez-Minguito, M., Caballero, I., López-Rodas, V., Prieto, L., Ruiz, J. 2012. Use of a Real-Time Remote Monitoring Network (RTRM) to Characterize the Guadalquivir Estuary (Spain)). Sensors 2012, 12, 1398-1421; doi:10.3390/s120201398

Sobrino, I., Baldó, F., García-González, Cuesta, J. A., Silva-García, A., FernándezDelgado, C., Arias, A. M., Rodríguez, A., Drake, P., 2005. The effect of estuarine fisheries on juvenile fish observed within the Guadalquivir Estuary (SW Spain). Fisheries Research 76, 229-242.

Taylor, A.H., Stephens, J.A., 1998. The North Atlantic Oscillation and the latitude of the Gulf Stream. Tellus 50A, 134-142.

Tesch, F. W., 2003. The Eel. Blackwell Science, Oxford. 408 pp. 
Tosi, L., Sola, C., Spampanato, A., Tongiorgi, P., 1989. The behavior of glass eel of Anguilla anguilla toward salinity: discrimination and preferences. Rivista Italiana Acquacoltura 24, 219-223.

Tosi, L., Sola, C., 1993. Role of geosmin, a typical inland water odour, in guiding glass eel Anguilla anguilla (L.) migration. Ethology 95, 177-195.

Vanney, J. R., 1970. L’hydrologie du Bas Guadalquivir. Madrid, Publicaciones del Departamento de Geografía Aplicada. C.S.I.C.

van Utrecht, W.L., Holleboom, M.A., 1985 Notes on eel larvae (Anguilla anguilla Linnaeus, 1758) from the central and eastern North Atlantic and on glass eels from the European continental shelf. Bijdragen Tot de Dierkunde 55, 249-262.

White, E. M., Knights, B., 1997. Environmental factors affecting migration of the European eel in the Rivers Severn and Avon, England. Journal and Fish Biology 50, 1104-1116.

Zompola, S., Katselis, G., Koutsikopoulos, C., Cladas, Y., 2008. Temporal patterns of glass eel migration (Anguilla anguilla L. 1758) in relation to environmental factors in the Western Greek inland waters. Estuarine, Coastal and Shelf Science 80, 330-338. 


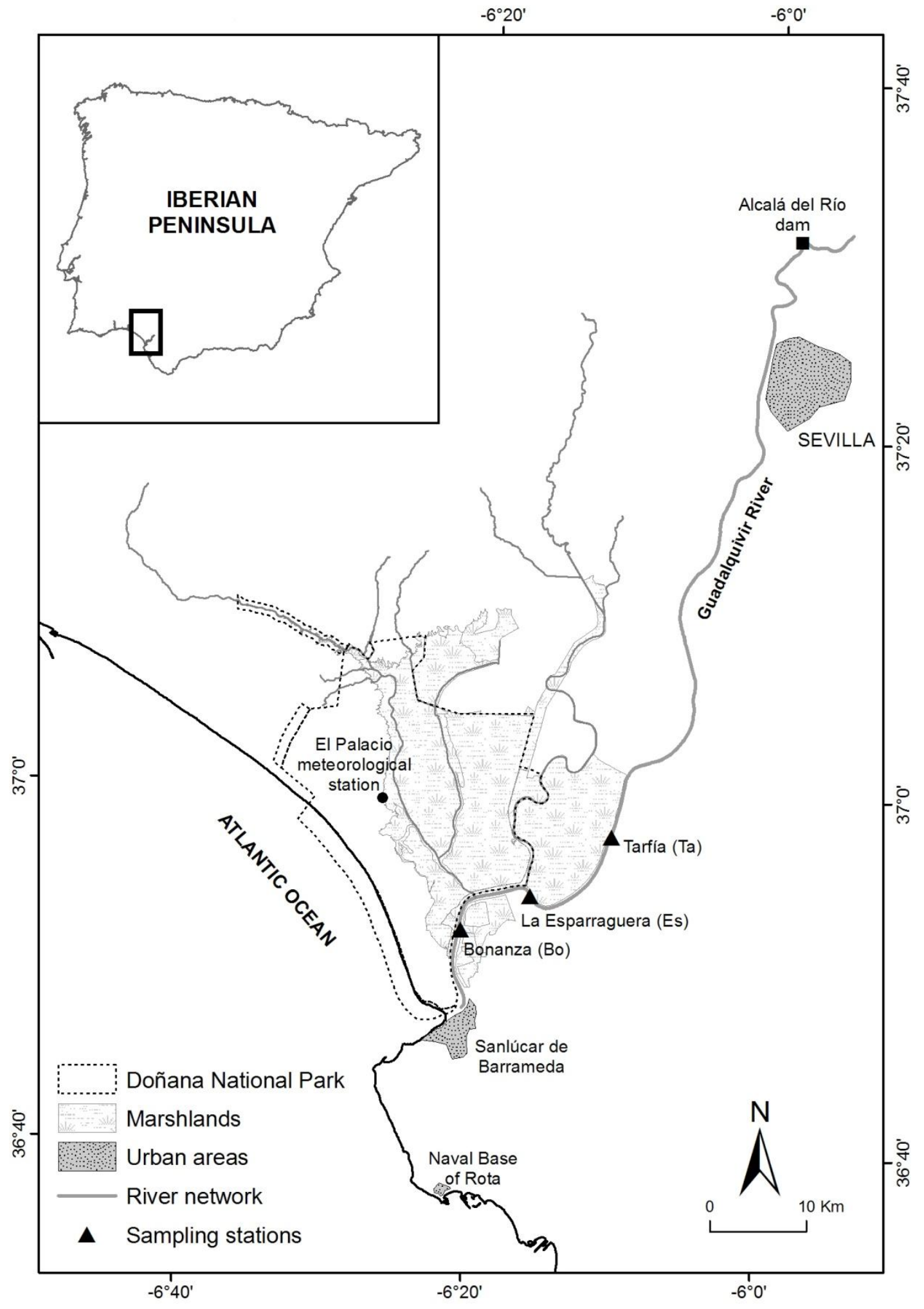

Fig.1. Map of the Guadalquivir River estuary (Southwest Spain) showing the location of the three sampling sites $(\boldsymbol{\Delta})$. 


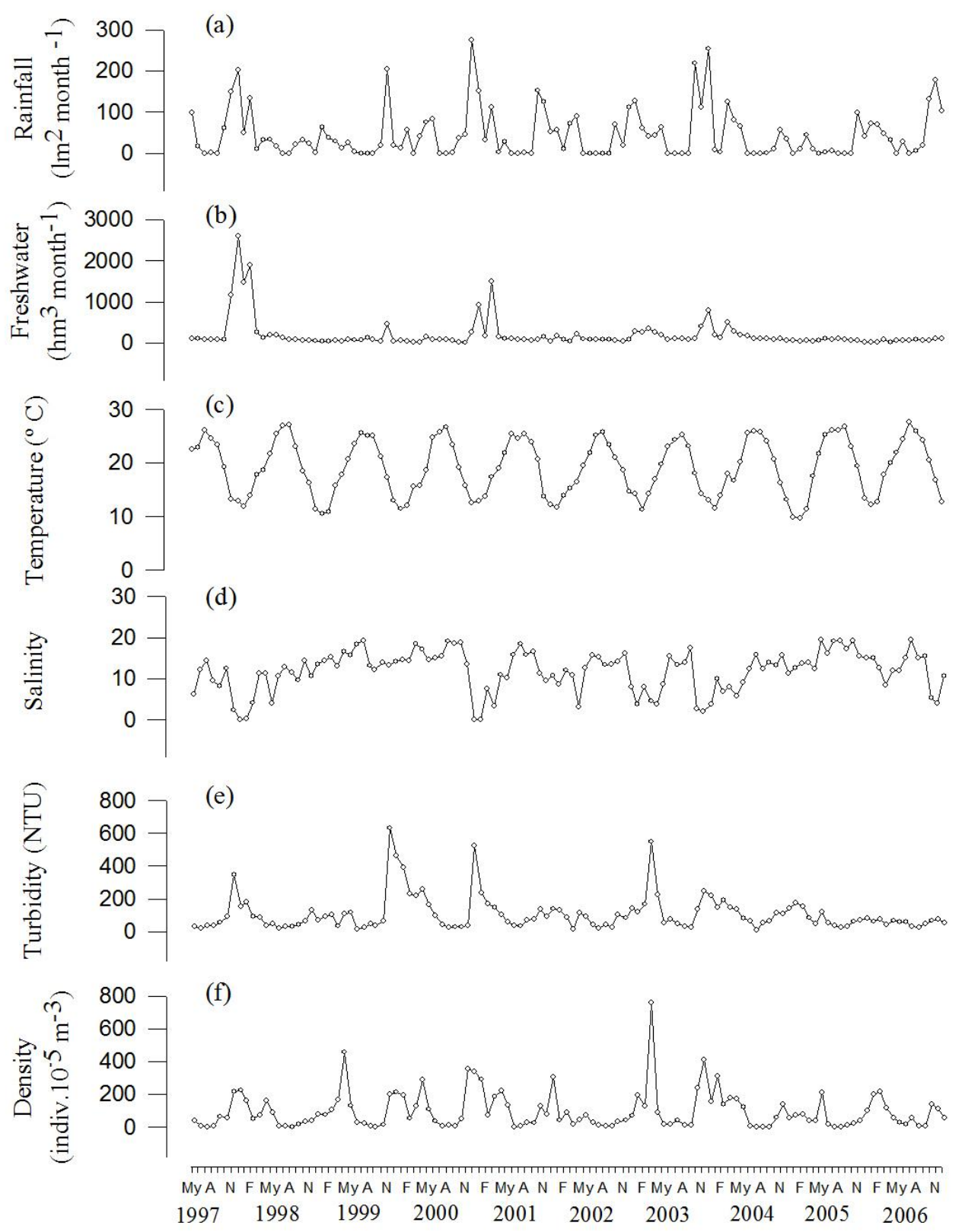

Fig.2. Monthly mean values of environmental variables in the Guadalquivir River estuary between June 1997 and December 2006 (a) rainfall, (b) freshwater input, (c) water temperature, (d) salinity, (e) turbidity and (f) glass eel density, F: February; M: May; A: August; N: November. 

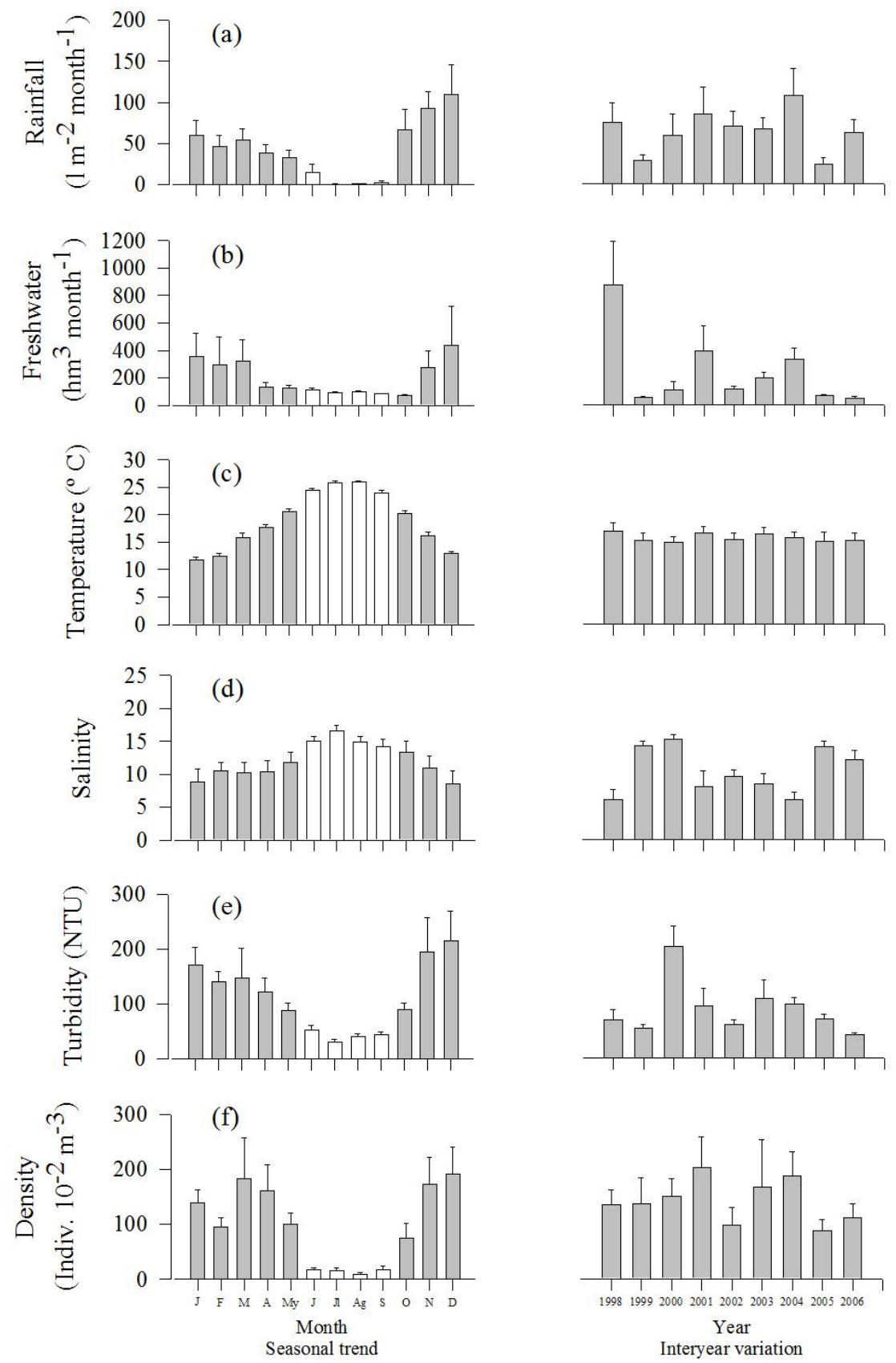

Fig.3. Mean (+S.E.) monthly (averages across years) and annual (averages across months) values of environmental variables in the Guadalquivir River estuary from June 1997 to December 2006: (a) rainfall, (b) freshwater input, (c) water temperature, (d) salinity, (e) turbidity and (f) glass eel density. J: January; F: February; M: March; A: April; My: May; J: June; Jl: July; Ag: August; S: September; O: October; N: November; D: December) during low $(\square)$ and high $(\square)$ recruitment periods. 

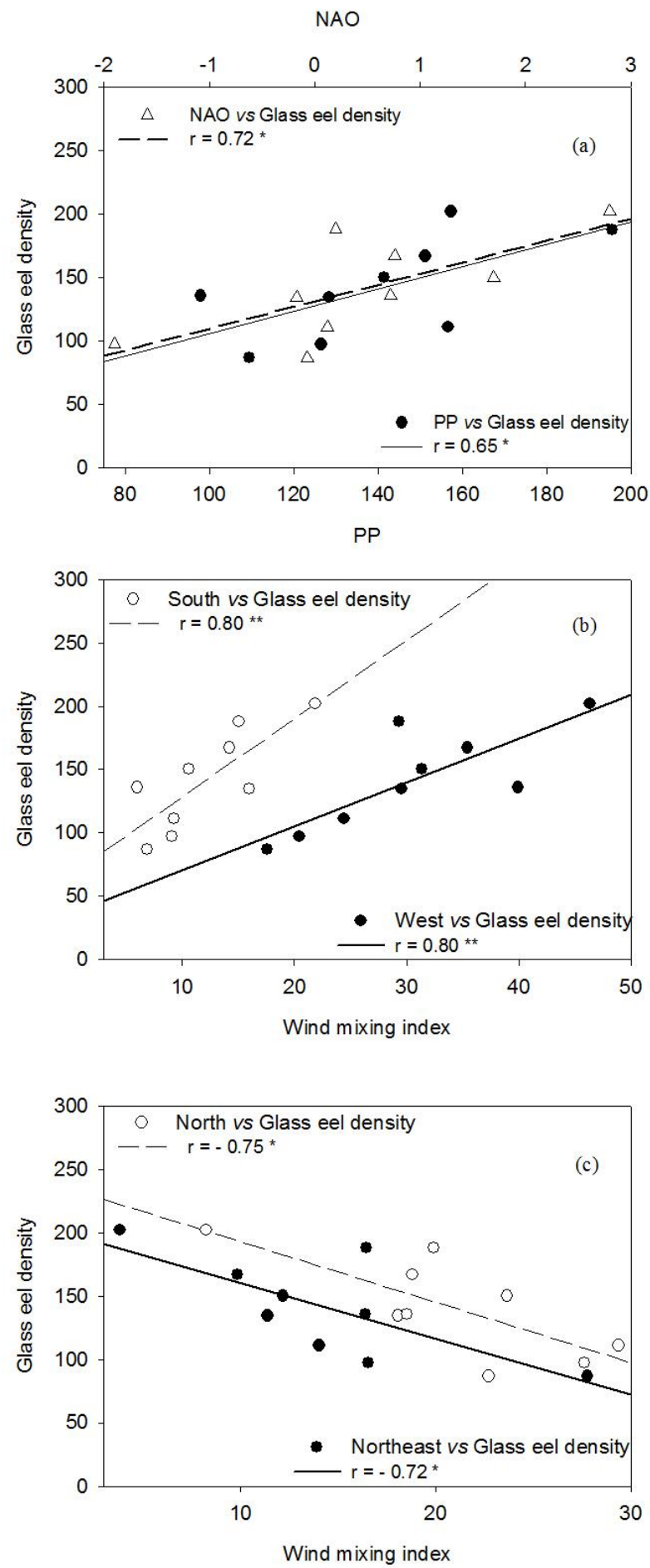

Fig.4. Relationships between mean annual Glass eel density in the Guadalquivir River estuary and environmental variables: (a) NAO winter index and primary production (PP) at the Sargasso Sea, (b) South and west wind mixing index and (c) North and Northeast mixing index. $r$, correlation coefficient. *, $\mathrm{p}<0.05 ; * *, p<0.01$. 

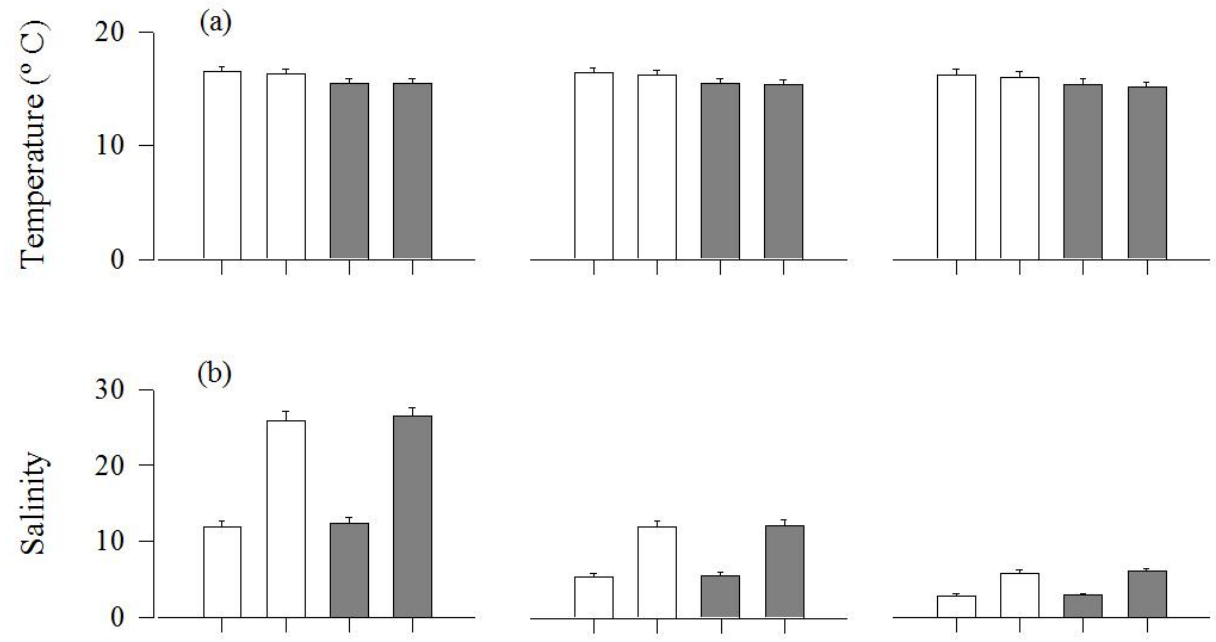

(c)
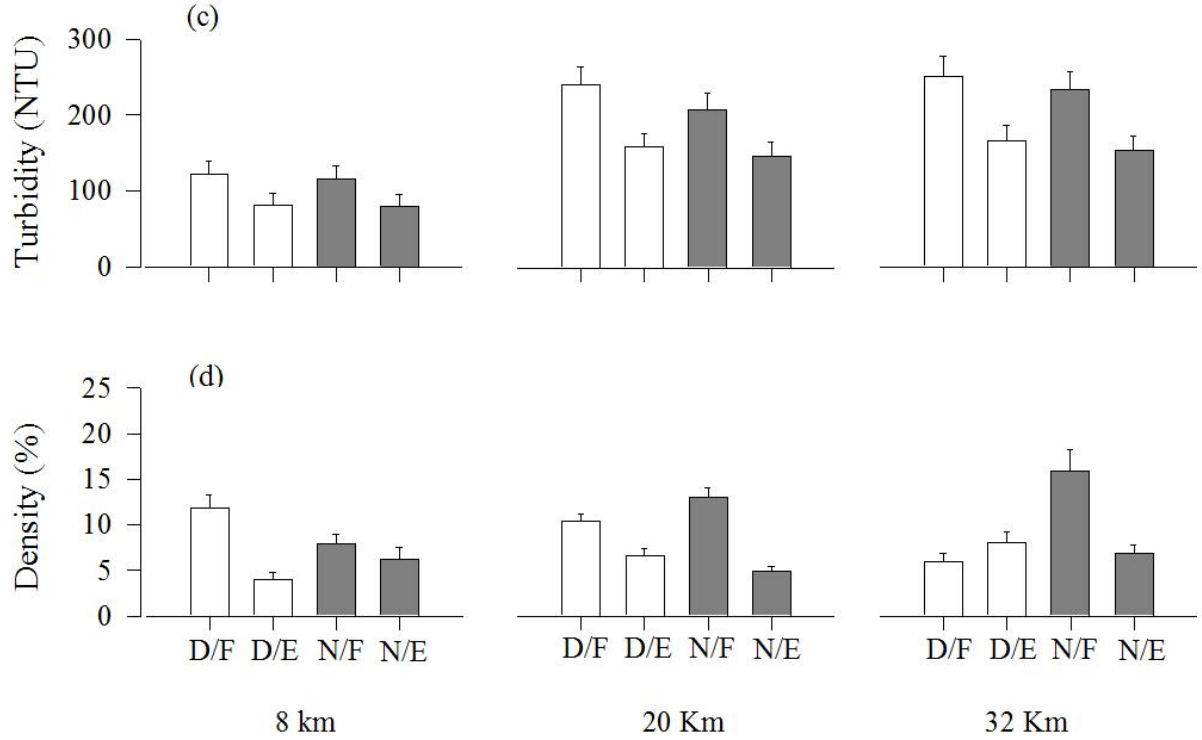

Fig.5. For each diel-tidal situation, mean + S.E values of environmental variables (a) water temperature, (b) salinity, (c) turbidity and (d) glass eel density during high recruitment period (October-May) at each sampling site in the Guadalquivir River estuary from June 1997 to December 2006 [F, flood; E, ebb; D, day time ( $\square$ ); N, night time ( $\square)$ ]. 
Table 1. Results of one-way ANOVA used to test the seasonal (inter-month) and diel-tidal/spatial differences, respectively, observed in Anguilla anguilla density from June 1997 to December 2006 at the Guadalquivir Estuary. Variable codes marked with the same letter were not statistically different. df: degrees of freedom; MS: mean square; P: p-level; F: flood; E: ebb; D: daytime; N: nighttime; for factor Month, 1 to 12 mean January to December; for factor Site, 32, 20, and 8 mean distance in Km from each sampling site to the river mouth.

\begin{tabular}{lllll}
\hline Variable & df & MS & p & Tukey HD Test
\end{tabular}

\section{Seasonality}

Month $11438.31<0.001 \quad 8_{\mathrm{a}}=7_{\mathrm{a}}<9_{\mathrm{ab}}=6_{\mathrm{ab}}<10_{\mathrm{abc}}<5_{\mathrm{bc}}=2_{\mathrm{bc}}<1_{\mathrm{c}}=4_{\mathrm{c}}=3_{\mathrm{c}}=11_{\mathrm{c}}=12_{\mathrm{c}}$

Residual $\quad 96 \quad 44.94$

\section{Diel/tidal-spatial distribution}

$\begin{array}{lcccl}\text { Site } & 2 & 0.20 & <0.001 & 8 \mathrm{a}<32_{\mathrm{b}}=20_{\mathrm{b}} \\ \text { Diel/tidal } & 3 & 0.65 & <0.001 & \mathrm{~N} / \mathrm{E}_{\mathrm{a}}=\mathrm{D} / \mathrm{E}_{\mathrm{a}}<\mathrm{D} / \mathrm{F}_{\mathrm{b}}<\mathrm{N} / \mathrm{F}_{\mathrm{c}} \\ \text { Interactión } & 6 & 0.16 & <0.001 & 8^{\mathrm{DE}}{ }_{\mathrm{a}}<8^{\mathrm{NE}}{ }_{\mathrm{ab}}=20^{\mathrm{NE}}{ }_{\mathrm{ab}}<32^{\mathrm{DF}}{ }_{\mathrm{abc}}<20^{\mathrm{DE}}{ }_{a b c d}=32^{\mathrm{NE}}{ }_{\text {abcd }}=8^{\mathrm{NF}}{ }_{\text {abcd }}<32^{\mathrm{DE}}{ }_{\mathrm{bcd}}<8^{\mathrm{DF}}{ }_{c d e}<20^{\mathrm{DF}}{ }_{\text {de }}<20^{\mathrm{NF}}<32^{\mathrm{NF}}{ }_{e}\end{array}$


Table 2. Results of permutation test (ANOSIM) carried out to analyze inter-year differences in mean Anguilla anguilla density during high glass eels recruitment periods from 1998 to 2006. R, global value of test statistic; P: p-level; 98 to 06, mean density during high glass eels recruitment periods of 1998 to 2006, respectively. For pairwise permutation test, codes marked with the same letter were not statistically different $(\mathrm{p}<0.05)$.

\begin{tabular}{llll}
\hline Variable & $\mathbf{R}$ & $\mathbf{p}$ & Pairwise test \\
\hline Year & 0.64 & $<0,01$ & $05_{\mathrm{a}}=02_{\mathrm{a}}=06_{\mathrm{a}}<98_{\mathrm{b}}=99_{\mathrm{b}}<00_{\mathrm{bc}}<03_{\mathrm{c}}<04_{\mathrm{d}}=01_{\mathrm{d}}$ \\
\hline
\end{tabular}


Table 3. Timing of high glass eel and elver abundance at different locations. Light gray $=$ fishing season/high recruitment period; dark gray = peaks of recruitment. ES, experimental survey; F, fisheries; A and M, Atlantic and Mediterranean coasts, respectively.

\begin{tabular}{|c|c|c|c|c|c|c|c|c|c|c|c|c|c|c|}
\hline \multirow{2}{*}{ Country } & \multirow{2}{*}{ Type } & \multirow{2}{*}{ Region (Coast) } & \multicolumn{12}{|c|}{ Month } \\
\hline & & & $\mathrm{O}$ & $\mathrm{N}$ & $\mathrm{D}$ & $\mathrm{J}$ & $\mathrm{F}$ & $\mathrm{M}$ & $\mathrm{A}$ & My & $\mathrm{J}$ & $\mathrm{Jl}$ & $\mathrm{Ag}$ & $\mathrm{S}$ \\
\hline Norway (Hvidsten, 1986) & ES & Imsa (A) & & & & & & & & & & & & \\
\hline Sweden (Wickstrom, 2002) & $\mathrm{F}$ & Viskan (A) & & & & & & & & & & & & \\
\hline N. Ireland (Moriarty, 1999) & $\mathrm{F}$ & Lough Neagh (A) & & & & & & & & & & & & \\
\hline N. Ireland (Rosell, 2002) & $\mathrm{F}$ & $\operatorname{Bann}(\mathrm{A})$ & & & & & & & & & & & & \\
\hline Ireland ( Moriarty, 1986) & $\mathrm{F}$ & Shanon (A) & & & & & & & & & & & & \\
\hline Denmark (D`Ancona, 1958; Boëtius and Boëtius, 1989) & $\mathrm{F}$ & Vida (A) & & & & & & & & & & & & \\
\hline Netherlands (Dekker, 1998) & $\mathrm{F}$ & DenOever (A) & & & & & & & & & & & & \\
\hline U. Kingdom (Naismith and Knights, 1988) & $\mathrm{F}$ & Thames (A) & & & & & & & & & & & & \\
\hline France (Desaunay et al., 1996) & $\mathrm{F}$ & Somme (A) & & & & & & & & & & & & \\
\hline France (Lafaille et al., 2007) & ES & Couesnon (A) & & & & & & & & & & & & \\
\hline France (Guerault et al ., 1992; Desaunay et al., 1996; Desaunay and Guerault, 1997; Briand et al., & $\mathrm{F}$ & Vilaine (A) & & & & & & & & & & & & \\
\hline France (Gascuel el al., 1995) & $\mathrm{F}$ & Loire (A) & & & & & & & & & & & & \\
\hline France (Gascuel el al., 1995) & $\mathrm{F}$ & Sévre Niortaise (A) & & & & & & & & & & & & \\
\hline France (Cantrelle, 1984; Gascuel el al., 1995) & $\mathrm{F}$ & Gironde (A) & & & & & & & & & & & & \\
\hline France (Desaunay et al., 1996; Casamajor et al., 2000) & $\mathrm{F}$ & Adour (A) & & & & & & & & & & & & \\
\hline Spain (Lara, 1994) & $\mathrm{F}$ & Nalón (A) & & & & & & & & & & & & \\
\hline Portugal (Weber, 1986; Antunes and Weber, 1996) & $\mathrm{F}$ & Miño (A) & & & & & & & & & & & & \\
\hline Portugal (Domingos, 1992) & $\mathrm{F}$ & Mondego (A) & & & & & & & & & & & & \\
\hline Spain (present study) & ES & Guadalquivir (A) & & & & & & & & & & & & \\
\hline Spain (Arias y Drake, $1985 ; 1990 ; 1991$ ) & ES & Bahía de Cádiz (A) & & & & & & & & & & & & \\
\hline Maroc (Yahyaoui,1988) & F & Sebou (A) & & & & & & & & & & & & \\
\hline Maroc (Yahyaoui, 1988) & $\mathrm{F}$ & Molouya (M) & & & & & & & & & & & & \\
\hline France (Lecomte-Finiger, 1976,1977 and 1983; Lecomte-Finiger and Razouls, 1981; Yahyaoui,1988) & ES & Bages sigean $(M)$ & & & & & & & & & & & & \\
\hline France (Lefebvre et al., 2003) & ES & Grau de la Fourcade & & & & & & & & & & & & \\
\hline Tunis (Held and Held, 1929) & ES & Tunisian lake (M) & & & & & & & & & & & & \\
\hline Italy (Gandolfi et al., 1984) & ES & $\operatorname{Arno}(\mathrm{M})$ & & & & & & & & & & & & \\
\hline Italy (Chiccotti et al., 1995) & $\mathrm{F}$ & Tiber $(\mathrm{M})$ & & & & & & & & & & & & \\
\hline Greece (Zompola et al., 2008) & ES & Sagiada (M) & & & & & & & & & & & & \\
\hline Greece (Zompola et al., 2008) & ES & Alfios (M) & & & & & & & & & & & & \\
\hline Turkey (Kucuk et al., 2005) & ES & Gozlen creek (M) & & & & & & & & & & & & \\
\hline Egypt (Paget, 1923) & ES & Pumping station (M) & & & & & & & & & & & & \\
\hline Egypt (Ezzat and El-Serafy, 1977) & ES & Mex canal (M) & & & & & & & & & & & & \\
\hline
\end{tabular}


